\title{
SİVIHIISAR'DA SÜRDÜRÜLEBİLİRLİK ÜZERİNE ÜÇ MİMARİ PROJE
}

\section{ÖzET}

Sivrihisar; adını eteğine kurulduğu sivri kayalardan alan, coğrafi konumunun yarattığı avantajlarla yüzyıllarca uygarlıkların yerleştikleri, Eskişehir'e $95 \mathrm{~km}$ uzaklıktaki tarihi kentlerden biridir. Birçok uygarlığın bıraktığı kültürel mirası korumakta ve kendi geleneksel kimliğini günümüzde de geliştirmeye devam etmektedir. Bu makale kapsamında Sivrihisar'ın sosyal ve kültürel sürekliliği devam ettiren yapıları toplumsal gelişim sürecinde incelenmiştir. Mimari tasarımı doğrudan etkileyecek olan topografyası, coğrafyası ve bitki örtüsü gibi fiziksel özellikleri de analiz edilmiştir. Sivrihisar'ın kendine has özellikleri ve kentsel yaşam döngüsü de göz önünde bulundurulmuş, hazırlanan kentsel iyileştirme projesi sunulmuştur.

Anahtar Kelimeler: Sivrihisar mahalle dokusu, Sürdürülebilirlik, Kültürel Süreklilik, Tarihi ve Kentsel Doku, Kentsel İyileştirme Projesi.

\section{THREE ARCHITECTURAL PROJECTS IN SIVRIHISAR AS SUSTAINABILITY PROCESS}

\section{ABSTRACT}

Sivrihisar is named after its sharp rocks "Sivri" on its hillside and many civilizations have settled throughout the centuries by advantages of geographical positions, located $95 \mathrm{~km}$ east from Eskişehir. Sivrihisar not only preserves many cultural heritages which presented to the history by civilizations, but also continue to develop a strong impression on its traditional identity. Within the scope of this article, in the process of social improvement many sivrihisar buildings have been investigated which leads social and cultural sustainability. Many physical characteristics that affect architectural design such as topography, geography and flora has been also analyzed. Sivrihisar's own characteristics and urban life-cycle has been considered, urban development project has been presented.

Keywords: Sivrihisar Texture of the Neighborhood, Sustainability, Cultural Continuity, Historical and Urban Texture, Urban Improvement Project. 


\section{GİİS (INTRODUCTION)}

Kentsel mekânın en temel özelliği, özel mekânın dışlayıcı karakterinin aksine, dâhil ediciliğidir. Ne kadar farklı olursa olsun kentte var olan hemen hemen her şeyi ve herkesi içine alır. Inceoğlu M., (2009:187-191)'nun tanımına göre kentsel mekân kentin ana bütünleşme aracıdır. Sakinlerin veya orayı kullananların başka hiçbir ortak özelliği olmayabilir, ama kenti paylaştıkları kamusal mekân her zaman vardır. Kentsel mekânlar kentlilerin ya da değişik kullanıcılarının kültürel birikimlerini paylaştığı, aktardığı, tekrar öğrendiği yerlerdir. Aynı zamanda bir kentin tanımlanması yani o kente dair imaj oluşumu bağlamında kullanıcılarının; kültürel kimliklerini, kişisel gelişimlerini ve birbirleriyle etkileşimleri sonucu kentli olma deneyiminin elde edilmesi de bu mekânlarda olmaktadır. Kentsel yaşam kültürle değiştiğinden ve geliştiğinden yeni ihtiyaçlara cevap verebilecek kentsel mekânlara ihtiyaç olabilmektedir. Varolan kentsel mekânlar ya tamamıyla hem biçimsel hem de işlevsel olarak değiştirilirler ya da var olan haliyle yenileştirilirler.

Eskişehir Anadolu Üniversitesi Mühendislik Mimarlık Fakültesi Mimarlık Bölümünün, Üniversite Rektörlüğü tarafından görevlendirmesi ile 2010 yılında "Topluma Hizmet Uygulamaları" kapsamında başlatılan projelerin geliştirilmesi hedeflenmiştir. Sivrihisar Belediyesi tarafından belirlenmiş olan, Nasrettin Hoca'nın kızı "Fatma Hatun'un Anıt Mezar" tasarımı, Sivrihisar Belediyesi Sergi Parkı ve Dinlenme Tesisi ve belediye tarafından itfaiye araçlarının parkı olarak kullanılan yerin "İ̧̧ Merkezi"; konulu projeler ihtiyaç programlarının tanımlanması ile çevre verilerinin ışığında tasarlanmış ve uygulanmak üzere ortaya konulmuştur.

\section{2. ÇALIŞMANIN ÖNEMI (RESERCH SIGNIFICANCE)}

$\mathrm{Bu}$ Çalışmanın amacı Eskişehir'in Sivrihisar yerleşiminde özgün kültürel ve tarihsel dokunun sürekliliğinin korunarak, yeni kentsel ihtiyaçların modern bir yorumla karşılanmasını sağlamaktır. Çalışma kapsamında Sivrihisar'ın tarihsel gelişimi, sahip olduğu özgün kentsel doku gibi kent yerleşimindeki önemli verileri de irdelenerek tasarlanan kentsel iyileştirme projeleri sunulmuştur.

\section{SİVIHIISAR' IN TARIHSEL BAĞLAMDA SÜRDÜRÜLEBİLİR GELİŞİM SÜRECí (HISTORICAL OVERVIEW OF SIVRIHISAR AS SUSTAINABLE DEVELOPMENT PROCESS)}

Tarihsel bağlamda incelendiğinde Sivrihisar'ın Hititler dönemine kadar eski bir geçmişi vardır. Doğru, H., (1992:14-19)'nun tespitlerine göre; Sivrihisar Etiler, Frigler, Roma, Bizans, Selçuklu dönemleri ile Bayezid ve Kanuni döneminde vilayet merkezi; 17. yy'a kadar Bursa sancağına, 1845 Osmanlı vilayet teşkilatının kuruluşu ile Ankara vilayetine, 1914 yılında Eskişehir sancağına ve Cumhuriyet devrinde 1925 yılında Eskişehir iline bağlı ilçe merkezi olmuştur.

Sivrihisar, Eskişehir'e 95 km., Ankara'ya $135 \mathrm{~km}$. mesafede, güneyinde Afyon'a ve güney doğusundan Konya'ya uzanan yollar kavşağında yer alır.

Sivrihisar, Ramsay (1960:218)'ya göre "Bizans ulaşım sistemi içinde, askeri yol ile posta yolunun düğüm noktasında orduların güvenli konaklama gereksinimlerinin karşılanmasına dönük olarak kurulmuş bir kent" olarak tanımlanmaktadır. Ayrıca ekonomik olarak milletlerarası düzeyde potansiyele sahip maden kaynaklarının güvenli olarak işletilmesi ve pazarlanmasına yönelik işlevlere de hizmet ettiği söylenebilir. Ramsay $(1960: 218)^{\prime}$ da belirtilenlere göre Bizans'ın yanı sıra diğer uygarlıkların da bu bölgeyi volkanik bir kaya kütlesi üzerinde askerî ve stratejik bir merkez olarak kullandıklarını söylemek mümkündür. Bu stratejiyi doğru kullanmak için 
de Kral Yolu üzerinde bulunan ve bu yolu kontrol eden Sivrihisar Kalesi'ni yaptırmışlardır. Bizanslılar bu kaleyi Sivrihisar'ın Ballıhisar köyündeki Antik Pessinus kentinden getirdikleri kesme taş, mermer parçaları ve moloz taşlardan yararlanarak inşa etmişlerdir. Günümüze sur duvar kalıntıları ile kale içerisindeki su sarnıçları, tahıl depoları ve yer altına yapılmış bazı mekânlar dışında pek fazla bir kalıntı gelememiştir. Bu kalıntıların yanı sıra Selçuklu döneminde kentte, "sarnıçlar, yiyecek ambarları ve cephanelikler ile mahzenlerin bulunduğuna ilişkin tespitlerin yapılmış olması da bölgedeki askerîstratejik niteliğin, kentin mekânsal yapısı ve öğeleri üzerindeki belirleyiciliğini ortaya koymaktadır." (Özcan 2008:94; Tevhit, 1929:130-132).

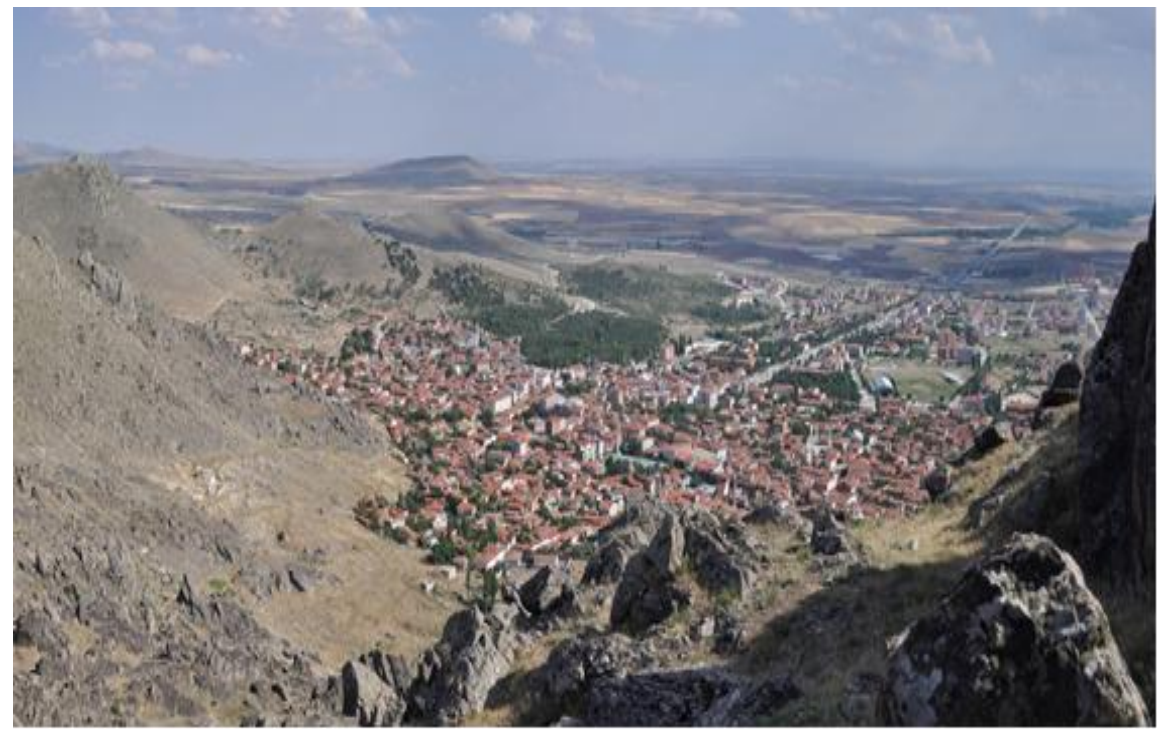

Resim 1. Sivrihisar genel görünüş [1]

(Figure1. General view of Sivrihisar [1])

\subsection{Kent Yerleşimi ve Mahalle Dokusu (Urban Settlement and Neighborhood Texture)}

Sivrihisar kent yerleşimini tanımlayan veriler bağlamında incelendiğinde mahalle dokusunun orijinal yapısını büyük çoğunlukta koruduğu görülmektedir. Sivrihisar, kuzey rüzgârını engelleyen hilal şeklindeki kayaların eteklerinde, doğal bir amfi gibi yüzeye yerleşmiş mahalleler konumundadır. Doğudan batıya aynı seviyede devam eden caddeleriyle birleşen sokakları ve bazen de çıkmaz sokaklarıyla zeminindeki Arnavut kaldırımları özgün mahalle dokusunu oluşturur. Mahalle aralarında çeşmelerin etrafında birleşen birkaç sokağın oluşturduğu küçük meydanların yanı sıra, bir ya da birkaç sokağın cadde ile kesiştiği yerlerde de meydanlar oluşmuştur. Anadolu'daki diğer eski kentler gibi burada da çoğu dar ve kıvrımıı, aynı zamanda evlerin cepheleri ve yüksek hayat duvarlarıyla sınırlandırılan sokaklar bu kent dokusunun korunduğu ve günümüze tarihi bir miras olarak taşındığı yerlerdendir. 


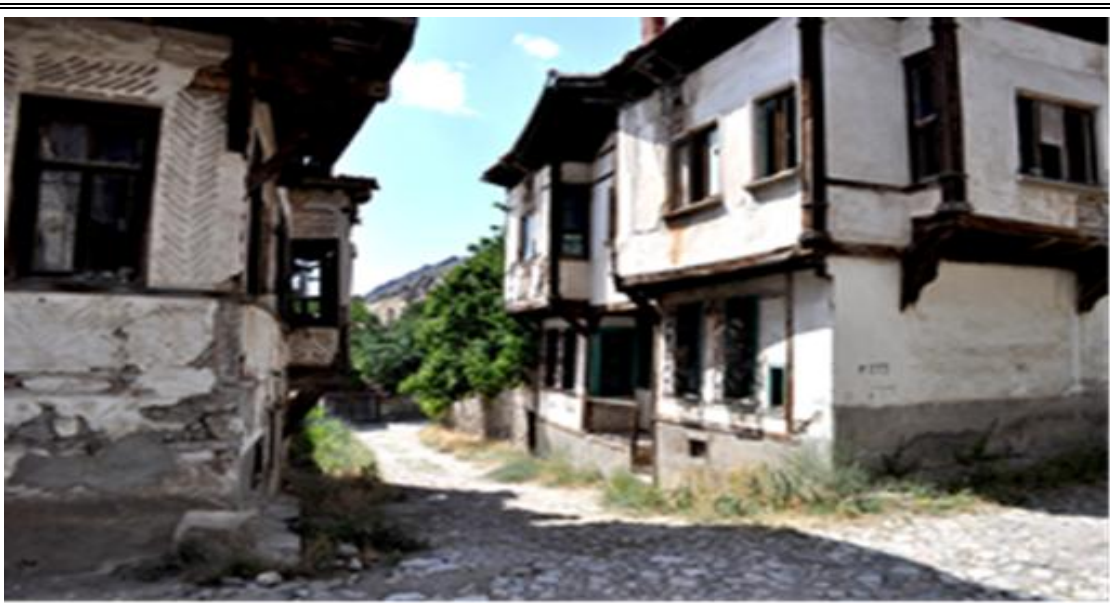

Resim 2. Sivrihisar konutları [1]

(Figure 2. Housing in Sivrihisar [1])

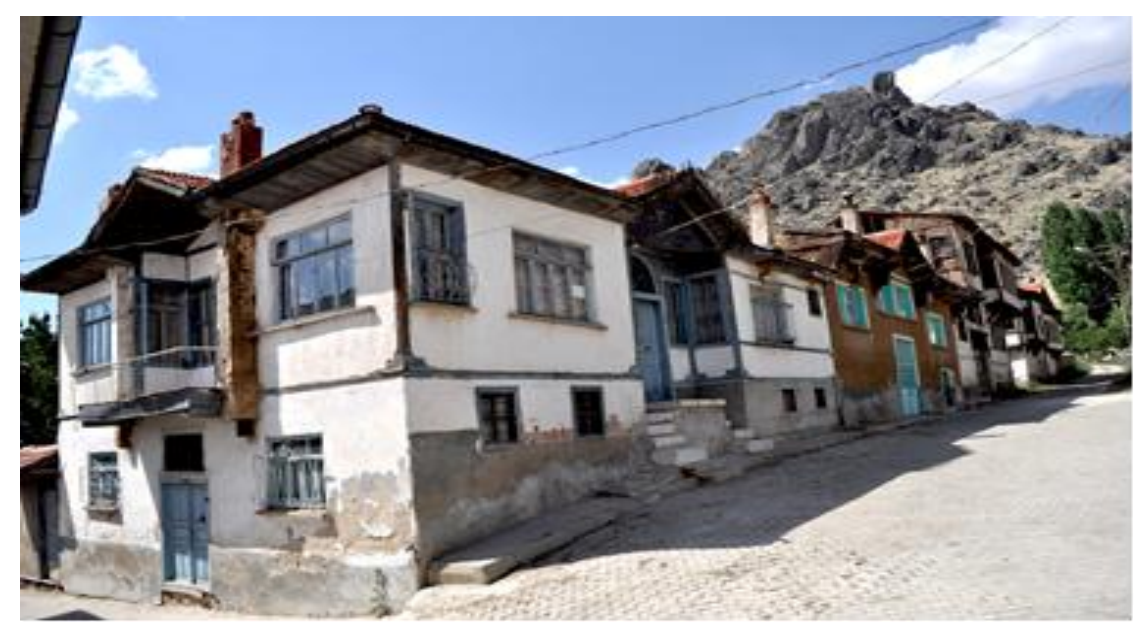

Resim 3. Sivrihisar mahalle dokusu [1]

(Figure 3. Texture of the neighborhood in Sivrihisar[1])

Doğru, H., (1992:21-22)'nun tespitlerine göre "Sivrihisar kuruluşundan bu güne Türk kentlerinin tüm özelliklerini taşımaktadır. XV ve XVI yy.da Sivrihisar kale, hanları, kervansaray, hamam, pazaryeri, çarşı-kapan, medrese ve camii merkezli, komşu hukukunu neredeyse mirasçılar arasındaki hukuka eşdeğer kabul eden adeta tek vücut yerleşmeler halinde idi". Mahallelerin bu denli iç içe ve bir arada yapılardan oluşması, ayrıca bu yapılardan Ermeni hamamı ile caminin ve ya medrese ile konutların yakınlıkları, bu dokunun yalnızca mimari bağlamda değil aynı zamanda sosyal olarak da hoşgörüyle oluşturulduğu göstermektedir. 


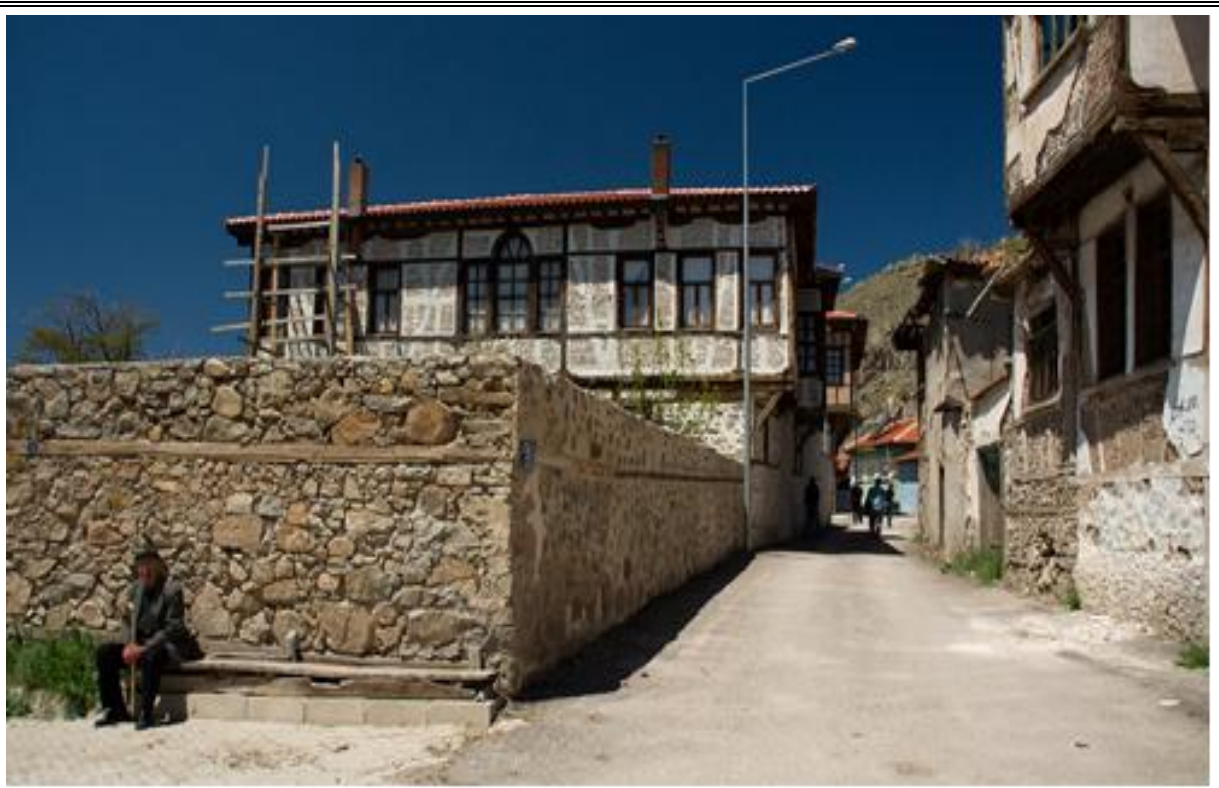

Resim 4. Sivrihisar'da restore edilen konutlar ve mahalle dokusu [2] (Figure 4. Sivrihisar restored homes and texture of the neighborhood [2] )

Kent yerleşiminde mahalle dokusunun yanı sıra konutlarda tanımlayıcı verilerdendir. Bu bağlamda incelendiğinde Sivrihisar'daki evler Orta Anadolu'da geleneksel Türk ev mimarisinin en tipik örneklerinin başında gelir. Doğru, H., (1992:23)'nun tespitlerine göre "Sivrihisar"da evler başlangıçta yüksek avlu duvarları ile dışa ve komşu mahremiyetine kapalı, avluya ve varsa bahçelerine açık bir konum sergiliyordu. Eski evler genellikle pederşahi ailelerin bir arada oturdukları geniş odalar yanında, yüklük adı verilen yatak ve yorganların konduğu ve altında ekseriya buğday ambarları bulunan kapakları ve çıkıntı teşkil eden yerleşik dolaplar ve ekseri bu dolaplara bitişik müstakil kapalı gusülhaneleri bulunan ailenin mali kuvvetine göre muhtelif odalardan müteşekkildi". Soğuk iklimsel özelliklerden dolayı "hayat"ların, evin etrafında dışarı kapalı olarak tasarlanarak konutun sıcak tutulmasına özen gösterildiği anlaşılmaktadır. Tüm bu tespitler doğrultusunda Sivrihisar'daki evlerin iklim şartlarına göre düzenlendiği ve çoğunlukla evlerin güneye bakan açık yüzlerinin önem kazandığı ve bilinçli olarak birbirinin görünümünü engellemeyecek şekilde konumlandırıldıkları görülmektedir.

Eski Türk evlerinin Sivrihisar'daki en seçkin örneklerinden olan Zaimoğlu Konağı mimarisi ve süslemelerinin özgünlüğüyle, yalnız Sivrihisar'da değil bütün geleneksel Türk konut mimarisi içinde bir değere sahiptir. Sayan (2003:97)'ın belirttiğine göre Zaimoğlu adıyla anılan Ali Zaimoğlu tarafından 1901 yılında yaptırılmıştır. Yüksek duvarlarla çevrili geniş bir bahçesi ve avlusu bulunmaktadır. Mekânsal organizasyonları Anadolu'daki Türk evlerine uymaktadır. İç sofalı plan tipinde yapılan konutun alt katı kiler, ambar, pekmezlik, kışlık oda gibi çeşitli hizmet birimlerine ayrılmıştır. Üst katları ise ikamet amaçlı yapılmış ahşap süslemelerce zengin odalardan oluşmaktadır. Genel karakteristiği, mimari elemanları ve mekansal çözümlerine bakıldığında minimalist bir yaklaşımı olan konağın, yapıldığı dönemin sürdürülebilir, ekolojik bina özelliklerini de taşıdığı görülmektedir. Bir başka açıdan, Kurtuluş Savaşı yıllarında Atatürk ve silah arkadaşlarının 24 Mart 1922'de ilk bakanlar kurulu toplantısını bu konakta yaptıkları bilinmektedir. Bu nedenle konağın tarihi ve 
kültürel değeri sanıldığından daha fazladır. Sivrihisar Belediyesi restorasyon çalışmalarının tamamlanmasıyla konağı müze olarak ziyarete açmıştır.

Sivrihisar'da konutlarında olduğu gibi, geleneksel yapıların birçoğu doğaya ve çevreye duyarlılık, iklimsel koşullara uyum, doğal malzeme kullanımı, sağlıklı ve konforlu yaşam çevreleri oluşturma gibi özelliklerle sürdürülebilir binalar sınıflandırmasına girmektedir.

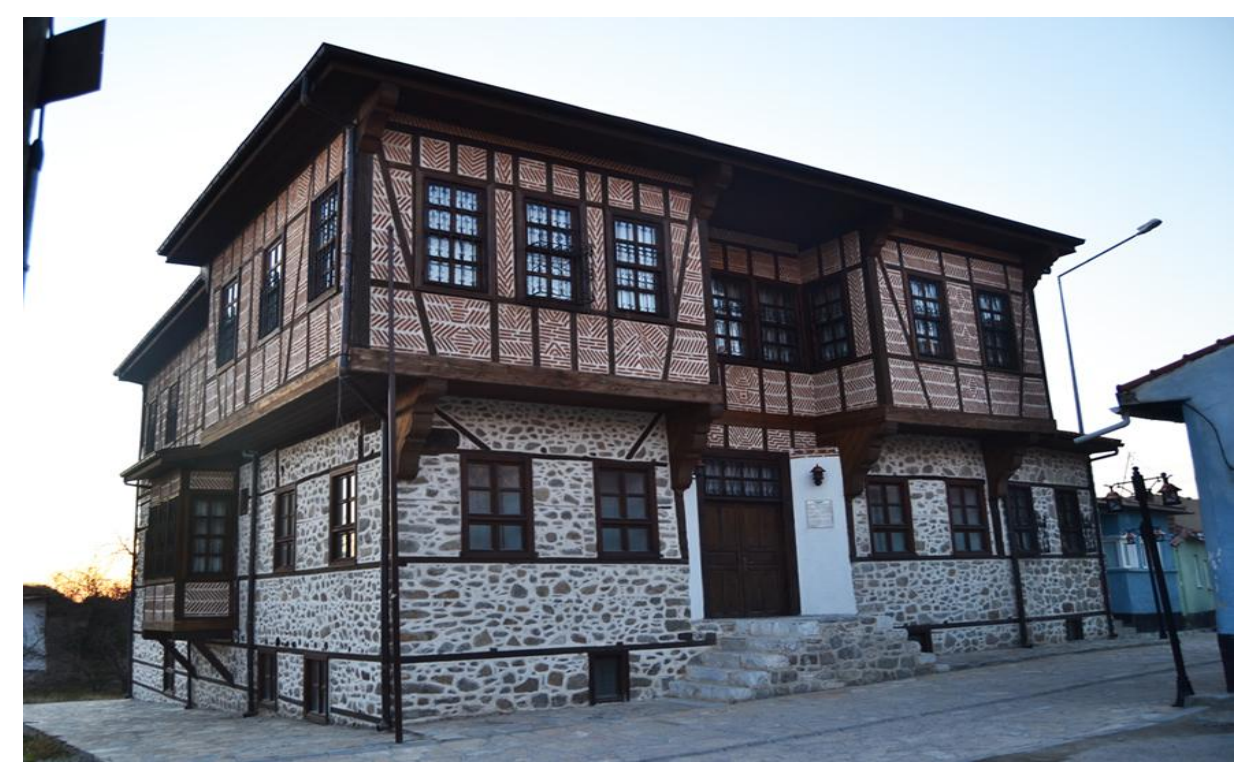

Resim 5. Zaimoğlu Konağı görünüş [2]

(Figure 5. The external appearance of the Zaimoğlu Konağı[2])

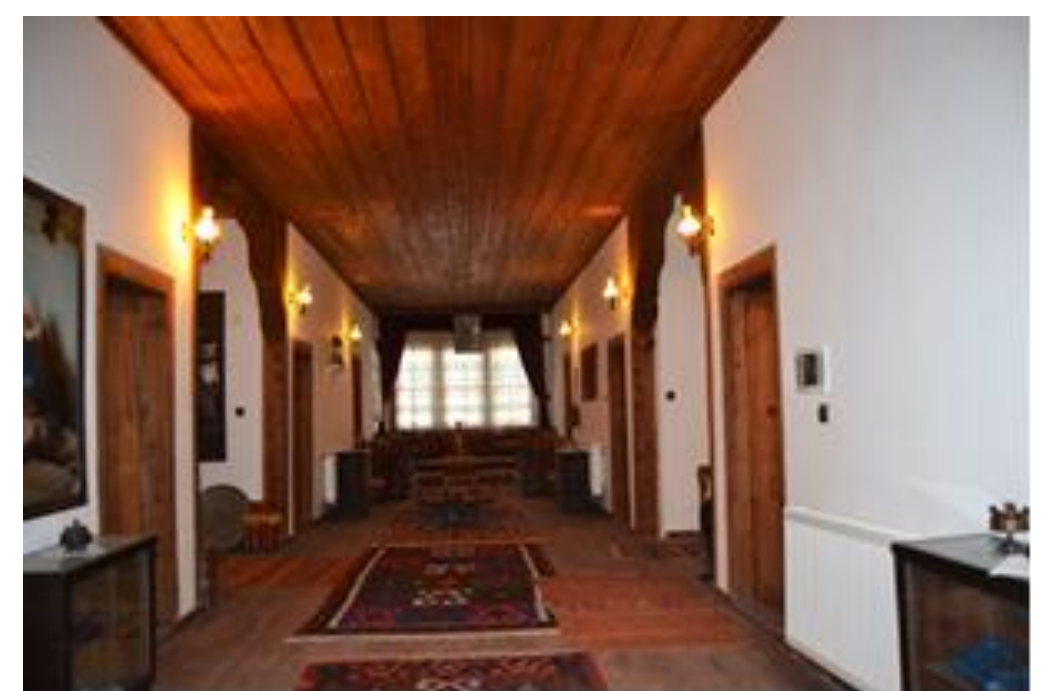

Resim 6. Zaimoğlu Konağı iç mekan görünüşü [2]

(Figure 6. The interior appearance of the Zaimoğlu Konăğ[2])

Sivrihisar konutlarının mekânsal ölçeği değerlendirildiğinde, büyük çoğunluğunun arazi yerleşiminin insani boyutlarda olduğu ve genel olarak dıştaki yalın görünüşüne rağmen içte zengin bir süsleme programına sahip oldukları söylenilebilir. Anadolu halkının sosyal eğilimlerinin doğayla kendiliğinden bütünleşerek, en iyi uyumu oluşturduğu mahalle dokusu, mekân organizasyonu olarak geleneksel Türk konutlarıyla birleştiğinde Sivrihisar'da özgün yapısını kültürel bir miras olarak korumaktadır. 
Mekânsal yapısının ve dokusunun yanı sıra Sivrihisar kent yerleşimini tanımlayan birçok tarihi, kültürel ve arkeolojik yapıyı da korumaktadır. Bunlardan biri de şehre hâkim kayalık bir tepe üzerinde bulunan Sivrihisar Saat Kulesi'dir. Acun, H., (1994:35)'un tespitlerine göre Kaymakam Mahmut Bey ile Belediye Reisi Yüzügüllü Hacı Mehmet Efendi tarafından 1900 yılında yaptırılmıştır. 1902-1903 tarihli Ankara Salnamesinde Saat Kulesinin 1898'de yapıldığını ve saatinin Avrupa'dan getirildiğini de belirtmiştir. Saat Kulesi $12 \mathrm{~m}$. yüksekliğinde ve kare prizma gövdelidir. Kuleye arka taraftaki sekiz basamaklı bir merdiven ile çıkllmaktadır. Üzeri kubbe ile örtülü demir parmaklıklı bir de şerefesi bulunmaktadır. Saat kadranı şehre hâkim bir yöne konulmuştur. 111 senedir Sivrihisar'da bulunan saat kulesinin alt kısmında Türk bayrağı ve Atatürk resmi vardır. Kent merkezi fikrinin hayata geçirilmesine yardımcı olan bu yapı türü, aynı zamanda ilçenin siluetine en az sivri tepeleri kadar etkileyici bir düşey öğe olarak da katılmış olur.

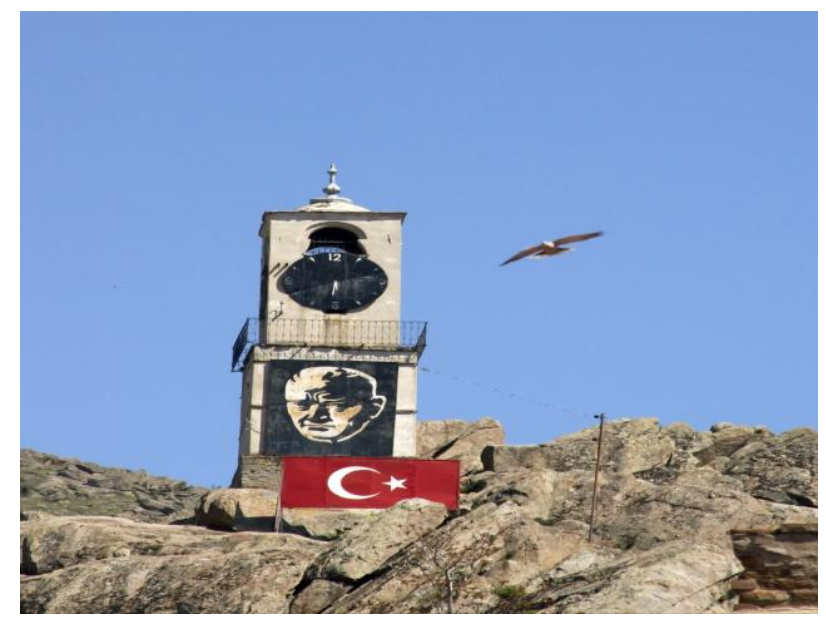

Resim 7. Saat Kulesi [3]

(Figure 7. Clock Tower [3])

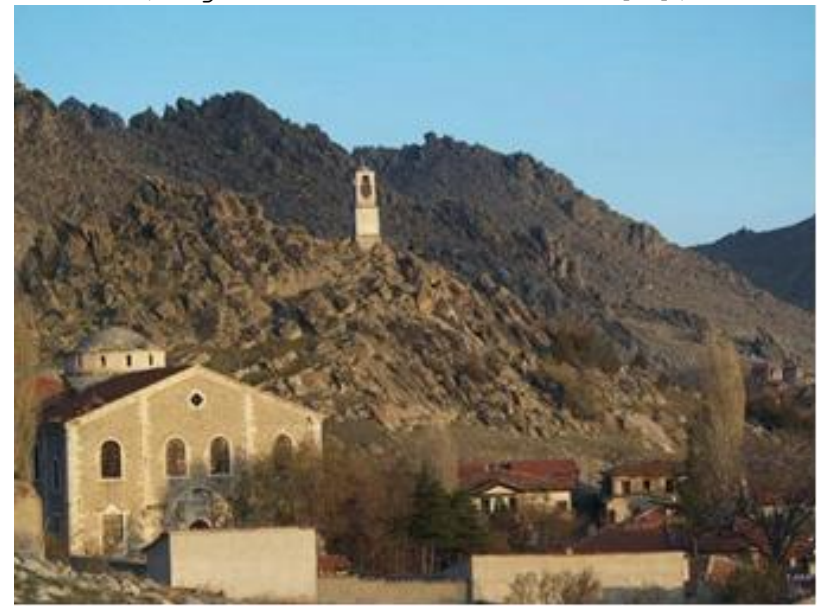

Resim 8. Saat Kulesi ve Ermeni Kilisesi [3]

(Figure 8. Clock Tower and The Armenian Church [3])

Sivrihisar'ın Kevser Caddesinde bulunan Tarihi Ermeni Kilisesi Altınsapan, E., (1988:56)'a göre 1881'de Ermeniler tarafından taş malzemeleri kullanılarak yapılmış dini ve sanatsal bir yapıdır. Anadolu'daki en büyük kiliselerden biri olduğu bilinen kilisenin ortasında büyük bir kubbe ve köşelerinde de iki büyük çan vardır. Girişi batı cephesindedir ve kapısında melek figürleri vardır. Ayrıca 
duvarlarda ve kaidesinde birçok yazıt ve kitabe görülmektedir. Sivrihisar Belediye Başkanı Fikret Arslan (2009)'ın belirttiğine göre kilise, Kültür ve Turizm Bakanlığı tarafından aslına uygun olarak restore edilerek sergi, konser ve toplantı salonlarının yer alacağı bir Kültür Evi'ne dönüştürülecek.

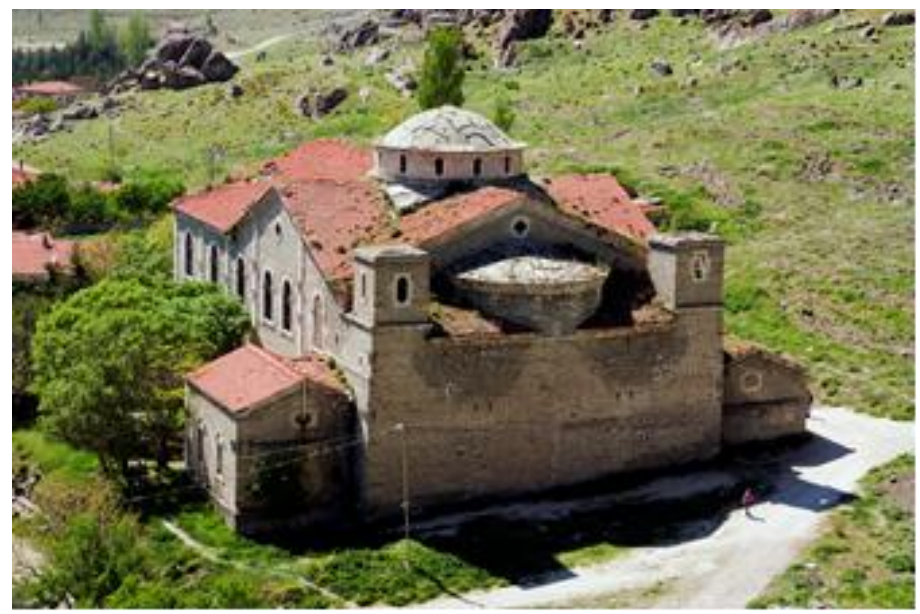

Resim 9. Restorasyon çalışmalarından önce Ermeni Kilisesi [3] (Figure 9. Previous version of the work of the Armenian Church Restoration [3])

Sivrihisar Ulu Cami Anadolu'nun en büyük ahşap direkli camilerinden biridir. Altınsapan,E.,(2004: 292)'a göre Selçuklu döneminde 1274 yılında Mevlana Celaleddin Rumi'nin müritlerinden ve II. Gıyaseddin Keyhüsrev'in naiplerinden Emineddin Mikail tarafından yaptırıldığı belirtilmektedir. $1485 \mathrm{~m}^{2}$ lik bir alana kurulu caminin çatısını atmış yedi adet ahşap direk taşımaktadır. Direklerin üst bölümleri rozet, palmet, geometrik ve bitkisel motiflerle bezenmiştir. Direkler üzerinde Bizans dönemine ait başlıklar da kullanılmıştır. Cami içerisinde ceviz ağacından oyma tekniği ile yapılmış dolap kapakları da bulunmaktadır. Caminin să̆ ve sol kanadı üzerinde kitabeler bulunmaktadır. Ulu cami'nin kitabesinde yazdığına göre caminin minaresi 1409 yılında Osman oğlu Hacı Habib tarafından yaptırılmıştır. Ayrıca, minberin el işçiliğinin Horasanlı İoni Mehmet tarafından geçme yöntemiyle yapıldığı belirtilmektedir. Sivrihisar el dokuması kilim örnekleri camide sergilenmektedir.

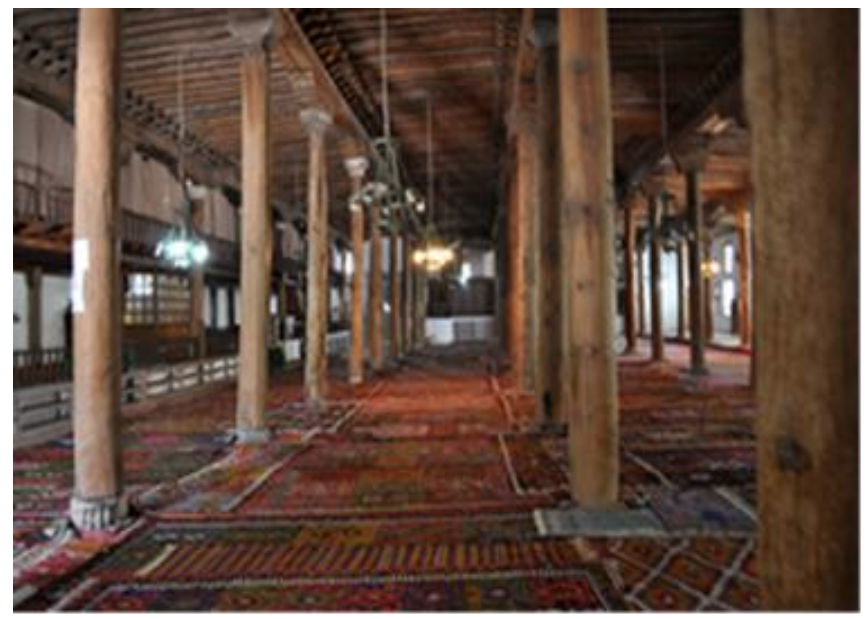

Resim 10. Ulu Cami iç mekan [2]

(Figure 10. The Grand Mosque interior [2]) 
Duvarlar kesme ve moloz taşlarla örülmüştür. Anadolu'daki birçok ahşap sütunlu cami gibi Sivrihisar Ulu Cami de yüz yıllar boyunca sağlam kalabilmiştir. Anadolu'da ayakta kalan ve basit bir forma sahip ahşap taşıyıcı sistemlerin düşey yükler altındaki yapısal davranışı Akan, E., (2010:43-44)'a göre "rijit taş duvarlar sayesinde, çatıyı oluşturan kirişlerin çerçeve sistemi yerine sürekli kiriş gibi davrandığı söylenebilir. Bu durumda ahşap dikmelerin de sadece eksenel yük taşıyan elemanlar olduğu kabul edilebilir. Ahşap dikmelerin, boyları nedeniyle ortaya çıkacak bir burkulma problemi olmadığı sürece önemli bir eğilme momentine maruz kaldıkları söylenemez" şeklinde yorumlanmıştır. Bu çalışmalardan anlaşıldığı üzere, Ulu Cami'nin ahşap taşıyıcı sisteminin, rüzgar ve deprem gibi yatay yük etkilerine karşı çatı strüktürlerini rijit bir şekilde çevreleyen masif taş duvarları sayesinde korunduğunu söylemek mümkündür. Ancak, bu tür camilerin yapısal performansını iyi bir şekilde sürdürebilmeleri için, özellikle ahşap yapı elemanlarının malzeme özelliklerinin ve bağlantı detaylarının bozulmamasına çaba harcanmalı ve iyi korunmalıdır.

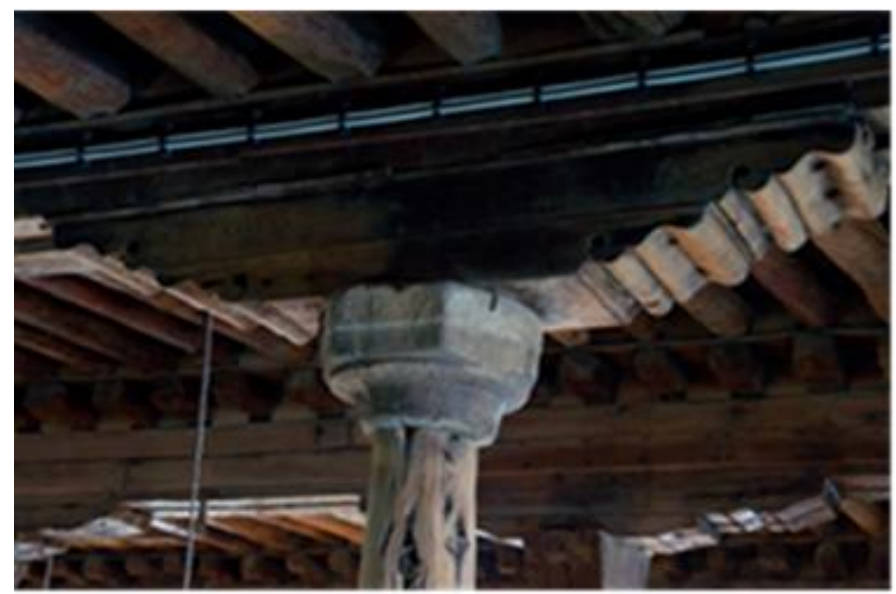

Resim 11. Ulu Cami ahşap taşıyıcı detayları[3]

(Figure 11. The Grand Mosque timber frame details[3])

Ulu Camínin kuzeyinde geniş bir avlu içinde yer alan Alemşah Kümbeti ise kapısının üstündeki kitabeden anlaşıldığına göre, Selçuklular zamanında Melik Şah tarafından, şehit edilen kardeşi Sultan Şah için 728 yılında yaptırılmıştır. Gündoğdu, H., (1982:133142)'ya göre Alemşah Kümbeti Anadolu Selçuklu türbe mimarisinin devamı sayılan bir yapı olmakla beraber, süslemesindeki bazı motifler orta Asya geleneklerine işaret etmektedir. 


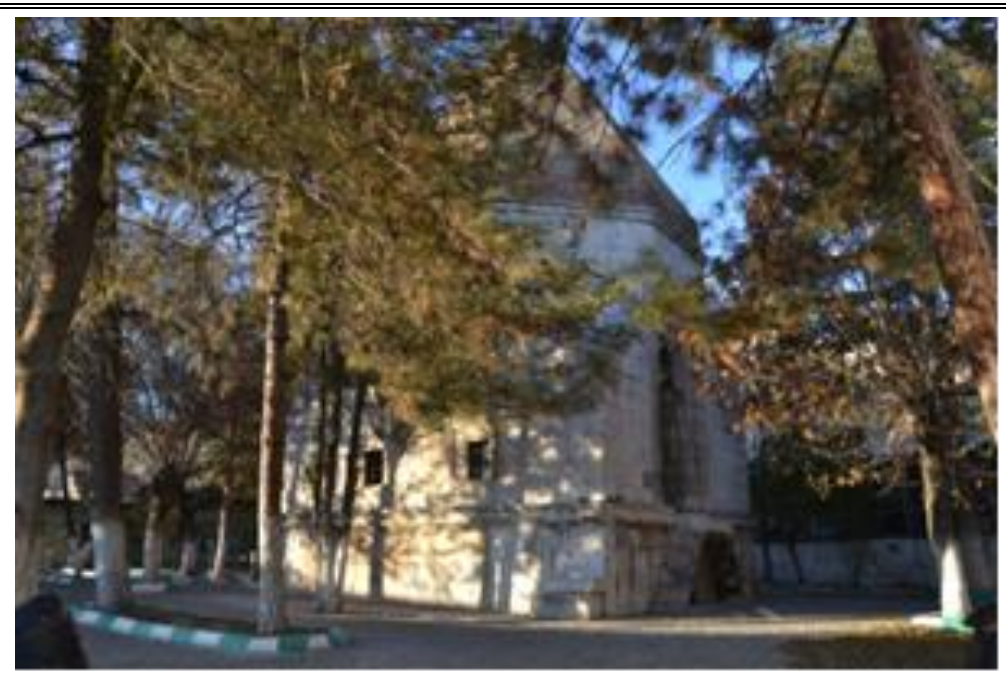

Resim 12. Alemşah Kümbeti [2]

(Figure 12. Vault of Alemşah [2])

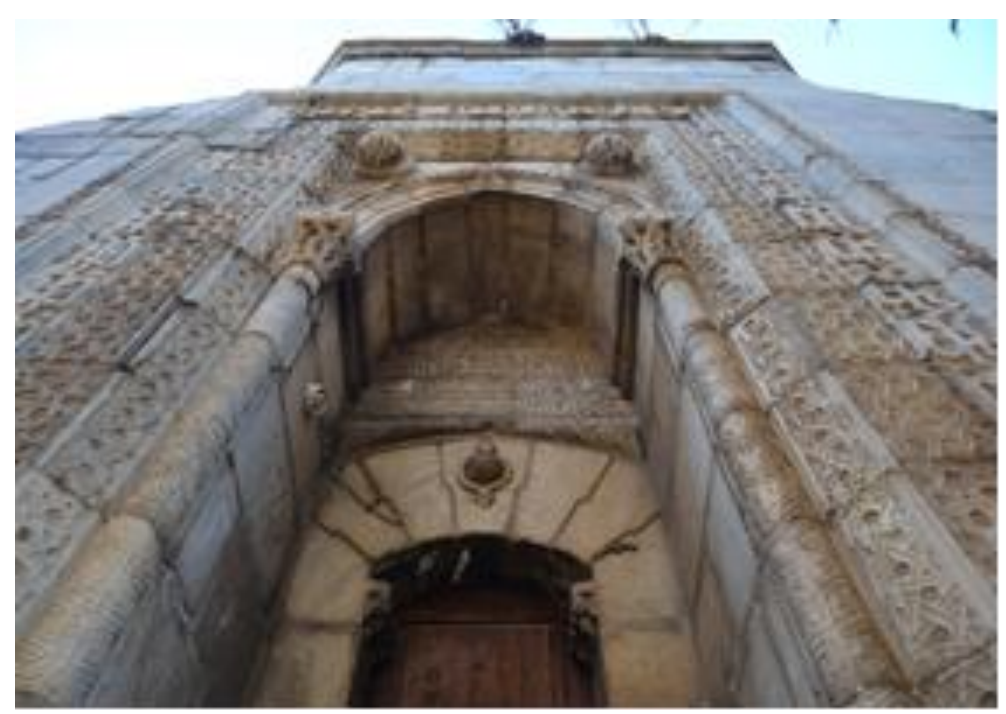

Resim 12. Alemşah Kümbeti'nin giriş kapısı [2]

(Figure 12. The main door entrance Vault of Alemşah [2])

Türbenin sekizgen gövdesi muntazam işlenmiş kesme mermer taşlarından yapılmış, üstü tuğladan yine sekiz dilimli bir piramit külahla örtülmüştür. İki taraflı merdivenle çıkılan üst mekâna zengin süslemeli bir niş içine açılmış kapıdan girilir. Bir duvarında mihrap olan bu mekânın altında esas mezar odası bulunmaktadır. Özalp, T., (1960:54)'e göre nispetleri bakımından biraz dar ve geometrik motiflerin hâkim olduğu çerçevelerle sınırlanmıştır. Bu çerçevelerde dal kıvrımları aralarında hayvan kabartmaları yer almaktadır.

\subsection{Yeraltı Kaynakları ve Hamamlar (Groundwater Resources and Baths)}

Yeraltı suları zengini olan Eskişehir'in ilçesi Sivrihisar'da da termal sularından dolayı hamamlar ve meydan çeşmeleri yaygın olarak kullanılmıştır. Bu hamamlardan Gâvur Hamamı Altınsapan, E., (1988:88)' ın belirttiğine göre "Ermeniler tarafından 1883'te yapılmış olmakla birlikte, geleneksel Osmanlı hamam mimarisinin tüm özelliklerini yansıtır. Bu eser Osmanlı döneminde azınlıkların geleneksel Türk mimari üslubu etkisinde kaldıklarını belgeleyen bir örnektir." Ayrıca kilisenin önündeki çeşmenin de bu hamamı besleyen su 
kaynağı olduğu düşünülmektedir. Çarşı içinde, Belediye Binasının yanında yer alan Kumacık Hamamı'nın 1407 yılından önce yapıldığı sanılmaktadır. Doğru, H., (1992:78)'nun tespitlerine göre XII. ve XIII yy. Türk hamamlarının karakteristik özelliğini taşıyan bu hamamın soyunmalık kısmındaki kagir kemer kalıntıları ile ılıklık, sıcaklık ve halvet bölümlerindeki kubbeler dikkat çekicidir. Hamam önceleri suyunu Tabakhane çeşmesinden alırken sonra şehir suyu şebekesinden almaya başlamıştır. Suyun yeterli olmadığı zamanlarda külhan avlusunda bulunan su kuyusu kullanılmıştır. Yeni Çifte Hamamı ise Abdurrahim Efendi tarafından 1274 tarihinde yaptırılmıştır. Hamamın, külhan kapısından girişte sol tarafta bir kuyusu bulunmaktadır. Hamam kadınlara ve yanında Erkeklere hitap etmek üzere çifte hamam olarak planlandırılmıştır seydi Mahmud Hz'leri Türbesi'nin karşısında yer alan Seydiler Hamamı ise 1490 yılında yaptırılmıştır. Günümüzde faal olan kullanılan hamam vakıflar adına tescillidir.

İlçede termal suların yanı sıra maden yatakları da bulunmaktadır. Eskişehir-Sivrihisar arasındaki çerçevede çalışan Kulaksız, S., (1981:103-109)'ın da belirttiğine göre1959 yılında MTA tarafından yapılan etütlerde Sivrihisar'ın kuzey çevresinde uranyum ve toryumun yanı sıra Nadir Toprak Elementlerini (NTE) de içeren bir saha saptanmıştır. Ayrıca dericilikte, tekstil sanayide ve boya endüstrisinde kullanılan krom yatakları da ilçe sınırlarında yer almaktadır.

\section{TOPLUMSAL GELENEK VE GÖRENEKLER (SOCIAL CUSTOMS AND TRADITIONS)}

Eskişehir ve çevresinde çeşitli dönemlerdeki göçler nedeniyle çok değişik geleneklerin yerleştiği bilinmektedir. Yerleşimin ilk dönemlerinden bu yana varlığını sürdüren Sivrihisar ilçesinde de Eskişehir'in ortak kültürel özellikleri ile gelenek ve görenekleri görülmektedir.

Sivrihisar'da bugün de yaşatılmaya çalışan el sanatları vardır. Örneğin dokumacılık yerleşik yaşama geçmiş olan Yörük ve Türkmen köylerinde oldukça önemli bir yer tutmaktadır. Özellikle Sivrihisar köylerinde ilginç kilim dokuma örnekleri mevcuttur. Sivrihisar Ulu Cami içerisinde de sergilenmekte olan bu kilim örnekleri günümüzde devam eden ve beğenilen geleneklerden biridir. Ev tezgâhlarında kilim ve dokuma üretimi Zey ve Yenidoğan köylerinde sürdürülmeye çalışılmaktadır. Son yıllarda kilimciliğin geliştirilmesi amacıyla Sivrihisar'a bağlı Kayakent'te kilim dokuma okulları açılmıştır. Ayrıca kilim dokumasının yanı sıra çorap, hırka, şalvar, sarka, bindallı gibi yöresel kıyafetlerin de işlemesi yapılmaktadır. Düğünler ve bayramlar gibi özel günlerde bu işlemeli yöresel kıyafetlerin giyilmesi bu kültürel geleneği devam ettirmektedir.

Sivrihisar'da ahşap işçiliği ustaları yaşanılan mekânlarda el sanatlarını uygulamaya yıllarca devam etmişlerdir. Tarihi konakların, evlerin ve dükkânların dış ve iç kısımlarında, özellikle tavan işlemeciliği, pencere, kepenk, yüklük, çiçeklik, lambalık gibi eşyaların yanı sıra günlük hayatta kullanılan ürünlerde de ahşap süslemeler görülmektedir. Ayrıca Sivrihisar'da, dış kapı kanatları üzerindeki dövme demir kapı tokmakları, işlevsel elemanlarının yanı sıra, zengin motif çeşitleri ile de dikkat çeker. Konutların iç ve dış mekânsal organizasyonlarının okunmasında bu ahşap işlemelerindeki farklılıklar yardımcı olmaktadır.

Sivrihisar'da iklimsel özelliklerden dolayı oluşan mekansal çeşitlilik, aynı zamanda zengin yemek kültürünün de oluşmasına katkı sağlamıştır. Geleneksel konutların alt katlarının yemek pişirme birimlerine ayrılmış olması bu kültürün mekansal organizasyonları da etkilediğini göstermektedir. Farklı mevsimlerde ve dönemlerde yetişen 
zengin malzemeler, özgün yemek çeşitliliğini günümüze de aktarmakta ve beğeni toplamaktadır. Bu zengin yemek kültürünün daha modern bir yaklaşımda halka sunulması kentin ihtiyaçları arasındadır.

\subsection{Sivrihisar'da Kültürün Yarattığı "Bilge Filozof" (Created Sivrihisar's Culture "wise" Philosopher)}

Nasreddin Hoca 1208 yılında Sivrihisar İlçesine bağlı Hortu Köyü'nde doğmuş olup, 13. yüzyılda yaşamış halk filozofu ve tasavvufçusudur. Dedebağı, C., (2010:19-21) Nasrettin Hocayı "hep eğriyi doğrultup, yanlışı düzeltmiş, hakkın, hukukun ve adaletin tecellisi için uğraşmış bir bilge" olarak tanımlamaktadır. Karakurt, S., (2010:37)'a göre Nasreddin Hoca "toplum yapısını gözlemleyerek toplumu iyi tanıyan, insani ilişkilere hakim, durumları ve olayları hazırcevaplık, nükte ve sağduyu ile çözümleyebilen bir filozof" olarak tanımlanabilir. Her şeyden önce kendisine özgüveni olan, kendisini nasıl ifade edeceğini bilen, bilinçli ve bilgelik vasıflarına sahip bir kişidir. Empatik bir toplum için gayret sarf eden eşsiz bir hoşgörüye sahiptir.

Mizahi zekâsı, fıkraları ve Sivrihisarlı olmasıyla anılan Nasreddin Hoca gibi bir bilgenin bu kentin kültürüyle büyüdüğü anlaşılmaktadır. Yalnızca sosyal hayatın en canlı sahnelerinin ve mekânsal kullanımların fıkralarıyla resmedildiği Sivrihisar'ı değil tüm milleti, medeniyetleri ve kültürleri etkileyebilecek kadar sevilmiş ve etkili olmuştur. Sivrihisar'da yapılan kazılar sonucunda Nasrettin Hoca'nın kızı Fatma Hatun'un mezarı da buradan çıkarılmıştır. Ancak henüz bir anıtı yapılmamıştır.

\subsection{Kentin Sosyal Kültürel ve Ekonomik Gelişim Durumu (Social Cultural and Economic Development State of the City)}

Sivrihisar binlerce yıl öncesine dayanan tarihiyle ve sosyal ve kültürel değerlerin büyük çoğunluğunun korunmuş olmasıyla tarih boyunca ticaret hayatının geçiş noktası olmuş, binlerce yıl bu önemini ve değerini korumuştur. Ancak günümüzde Sivrihisar Belediyesi'nden edinilen bilgilere göre eğitim, ulaşım, ticaret ve sanayi gibi birçok konuda ihtiyaçların karşılanamamasından dolayı yoğun olarak göç yaşanmaktadır.

Sivrihisar Kaymakamlığı'ndan (Arşiv, 2011) edinilen bilgiye göre Eğitim kurumları, sosyal tesisler ve spor alanları açısından yeterli düzeyde olmayan ilçede yirmi dört adet ilköğretim okulu ve sekiz adet lise vardır. İlçede ticaret ve sanayinin yeterince gelişmemiş olması ve tarım alanlarının da zamanla küçülmesiyle halkın geçimini sağlayamadığı anlaşılmaktadır. Nüfusu 2000 yılı sayımına göre 31.664 olup, halkın 21.117'si (\%66.7) köylerde, 10.547'si (\%33.3) ilçe merkezinde yaşamaktadır. Sivrihisar, $3000 \mathrm{~km}^{2}{ }^{\prime} \mathrm{lik}$ yüzölçümü ile Türkiye'nin toprak olarak en büyük ilçelerinden biridir. Ayrıca topraklarının çok büyük bir kısmı ekilebilir arazi niteliğindedir. İlçede otuz üç tane tarım kooperatifi bulunmaktadır. Halkın o80 inin geçim kaynağı tarım ve hayvancılıktır. Buğday, pancar ve soğan da başlıca tarım ürünleridir.

\section{SÜRDÜRÜLEBİLIR PROJELER (SUSTAINABLE PROJECTS)}

Sivrihisar tarihi geçmişi, mimarisi, örf, adet, gelenek ve görenekleri gibi birçok sosyal, kültürel ve tarihi mirasını günümüzde yaşatmaktadır. Ancak kentteki yaşam kültürle değiştiğinden ve geliştiğinden, bu modern çă̆da yeni ihtiyaçlara cevap verebilecek kentsel mekânlara ihtiyaç duymaktadır. Sivrihisar'daki ticaret merkezlerinin ve sosyal tesislerin eksikliği, aynı zamanda halkın geçimini tarımdan ve hayvancılıktan sağlayamaz hale gelmiş olması 
kentin göç vermesine neden olmaktadır. Kent bütünüyle ele alındığında daha çok sosyal alana, yeşil alana, alışveriş ihtiyaçlarının giderilebileceği tesislere ihtiyaç duymaktadır.

Anadolu Türk konut mimarisinin en güzel örneklerini barındıran, zengin yemek kültürü beğenilen, birçok tarihi ve kültürel yapıyı ve özgün dokuyu koruyan bu kentin, sakinlerinin ve ziyaretçilerinin ihtiyaçlarının giderilmesi gerekmektedir. Bu bağlamda Sivrihisar Belediyesi tarafından belirlenmiş olan, Nasrettin Hoca'nın kızı "Fatma Hatun'un Anıt Mezar" tasarımı, Sivrihisar Belediyesi sergi Parkı ve Dinlenme Tesisi ve belediye tarafından itfaiye araçlarının parkı olarak kullanılan yerin "İş Merkezi"; konulu projeler ihtiyaç programlarının tanımlanması ile çevre verilerinin ışığında tasarlanmıştır.

Özmehmet, E., (2007:812) "Sürdürülebilir binalarda üç alt sürdürülebilirlik göstergesi öne çıkmaktadır. Bunlar; ekolojik sürdürülebilirlik, ekonomik sürdürülebilirlik ve sosyal/kültürel sürdürülebilirliktir." tanımını yapmaktadır. Bu tanıma göre sürdürülebilirlik;

- Ekolojik olarak kaynakların ve ekosistemlerin korunması,

- Ekonomik olarak; kaynakların verimliliği, kullanım ve bakım maliyetlerinin düşük olması,

- Sosyal ve kültürel anlamda; konforun, sağlığın ve sosyalkültürel değerlerin korunmasıyla ölçülebilir.

Bourdeau, L., (1999, Özmehmet, 2007:812) bir bina tasarlanırken, içinde bulunduğu kentin ya da bölgenin fiziksel dokusunun yanı sıra sosyoekonomik doku üzerindeki geçmişten kaynaklanan ve gelecekte de karşılaşacağı zararların da göz önünde bulundurulması gerektiğini belirtmiştir. Sivrihisar'da sürdürülebilir projeler tasarlama çabası gelecekteki yaşam çevrelerini oluşturmak için benimsenmesi gereken hedefleri barındırmaktadır. Bu hedefler;

- Kent yerleşimindeki bütün insanların kaliteli bir yaşam sürmesi

- Insanların, sosyal ve kültürel gereksinimlerine cevap verebilecek bir uygulama sunulması,

- Mevcut çevresel değerlerin ekolojik ve sürdürülebilir gelişiminin sağlanması,

- Tüm kullanıcıların benimseyip, sorumluluk hissettiği ve değer verdiği bir mimari projenin ortaya çıkması şeklinde siralanabilir.

Bu bağlamda ortaya çıkan tasarımlar günümüzdeki sürdürülebilir mimari tasarım anlayışını yansıtmaktadır. Tasarlanan bu sürdürülebilir projeler doğal kaynaklara saygı gösteren, kültürel ve tarihsel farklılıkları benimseyen tasarım ürünleridir. Modern anlayışta bütüncül bir yaklaşımla ele alınmıştır.

\subsection{Nasrettin Hoca'nın Kızl Fatma Hatun' un Anıt Mezar Tasarımı (Nasreddin Hodja's Daughter Fatma Hatun Mausoleum Design)}

Eskişehir'in Sivrihisar İlçesi'nde yapılan kazılar sonucunda çıkarılan Nasrettin Hoca'nın kızı Fatma Hatun'un mezarı için Eskişehir-Sivrihisar yolundaki Nasrettin Hoca Anıt Parkı'nın bulunduğu alana bir anıt mezar tasarlanmıştır. Mimari tasarım ve çevre düzenlemesini kapsayan Anıt park, Nasrettin Hoca heykeli ve ön tarafındaki alanla birlikte yaklaşık $85 \mathrm{~m}^{2}$ lik alanı kaplamaktadır. Anıt parkın çevresinde yeşil alan ve yetişkin ağaçlar mevcuttur. Parkın batı tarafında çarşı olarak kullanılan alan ve yapı bulunmaktadır.

Anıt mezar projesi Nasrettin Hoca heykelinin ön tarafındaki boşluğa konumlandırılmıştır. Anıt tasarlanırken modern bir yaklaşım sergilenmiştir. Anıt tek bir kütle olarak değil birçok parçadan, 
sütunlar, çerçeve, çeşmeler ve duvarlar, oluşacak şekilde tasarlanmıştır. Anıt mezar kısmı sütun ve çerçevelerin oluşturduğu mekân da konumlanmıştır. Anıtın çevresinde bulunan ve anıta ulaşım yerlerinde bulunan duvarlarda ise Nasrettin Hoca'yı, kızını ve fıkraları anlatan yazıların bulunduğu bölümler yer almaktadır. Yapılan literatür araştırmaları sonucunda Nasrettin Hoca'nın hayatı, yaşadığı olaylar, kızı hakkında bilgiler elde edilerek, insanlara bilgi vermesi amacı ile anıtta yer almasına karar verilmiştir. Nasrettin Hoca'nın ders veren fıkralarına da anıtta yer verilmiştir. Duvarlar bazı yerlerde çeşmeye dönüşerek serin bir dinlenme mekânı oluştururken aynı zamanda suyun oluşturduğu sesle insanı dinlendiren bir ortam oluşturulmuştur.

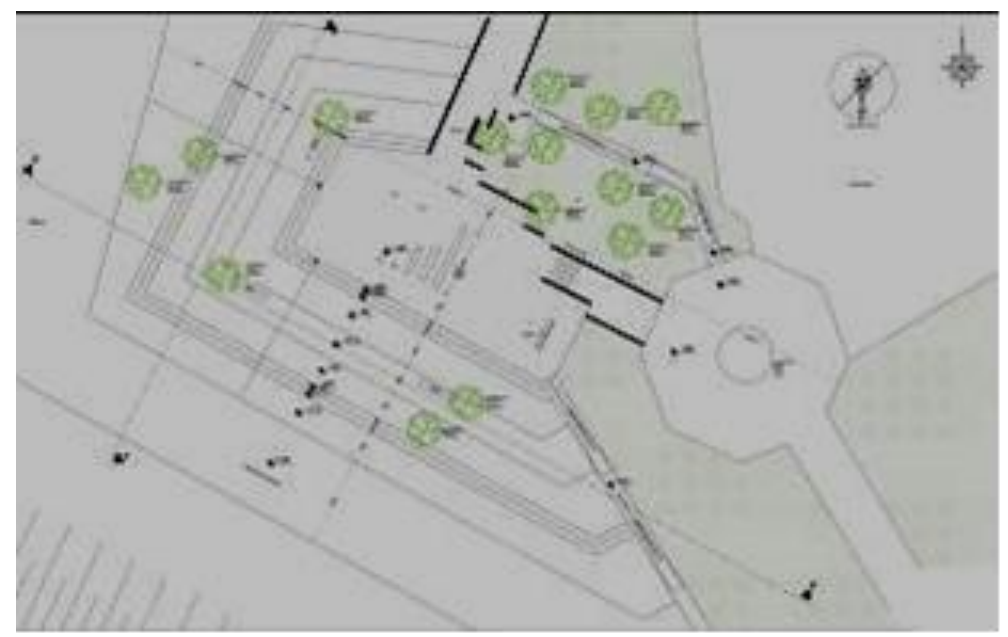

Resim 14. Nasrettin Hoca'nın Kızı Fatma Hatun'un Anıt Mezar Vaziyet Plani [4]

(Figure 14. Site Plan of the Nasreddin Hodja's daughter Fatma Hatun Mausoleum Memorial grave[4])

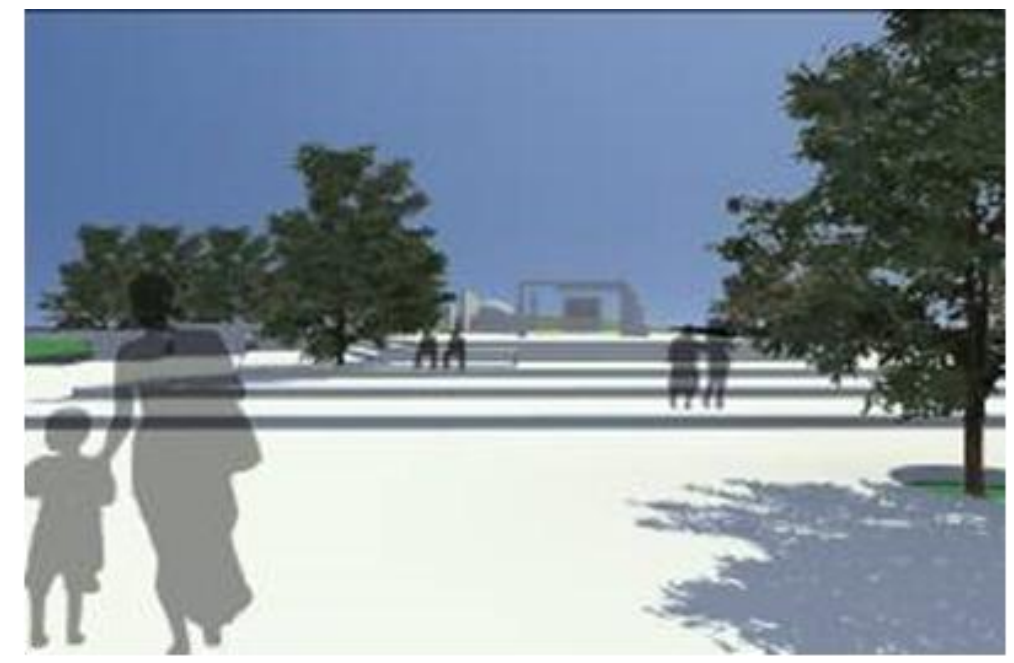

Resim 15. Nasrettin Hoca'nın Kızı Fatma Hatun'un Anıt Mezarı perspektifi [4]

(Figure 15. Perspective of the Nasreddin Hodja's daughter Fatma Hatun Mausoleum Memorial grave[4])

Anıt mezar tasarımında ön planda tutulan diğer konular ise erişilebilirlik ve yeşil alandır. Anıta ulaşımın ve gezi alanlarının rahat ve keyifli mekânlar olmasına dikkat edilmiştir. Bu amaçla anıta 
ulaşım basamaklar ve rampalarla sağlanmıştır. Erişilebilirlik açısından ise farklı kotlarda ayrı ayrı engelli rampası bulunurken, anıt mezar ve heykel arasına da rampa konulmuştur. Rampalara o6 eğim verilerek ulaşımın en rahat şekilde yapılaması sağlanmıştır. Basamaklar anıtın güney ve batı tarafında kesintisiz olarak devam etmektedir. Sadece ulaşım amaçlı olmayan basamaklarda, farklı kotlarda farklı genişliklere yer verilerek dinlenme alanları ve oturma birimleri oluşturulmuştur. Anıt mezar ve çevresi tasarlanırken yeşil alanın yok olmasına izin verilmemiş ve özellikle mevcut yeşilin ve ağaçların korunması ve tasarıma katılması sağlanmıştır. Tüm mevcut ağaçlar korunarak dinlenme alanları ve oturma birimleri bu ağaçların oluşturduğu gölgeliklerde konumlandırılmışlardır.

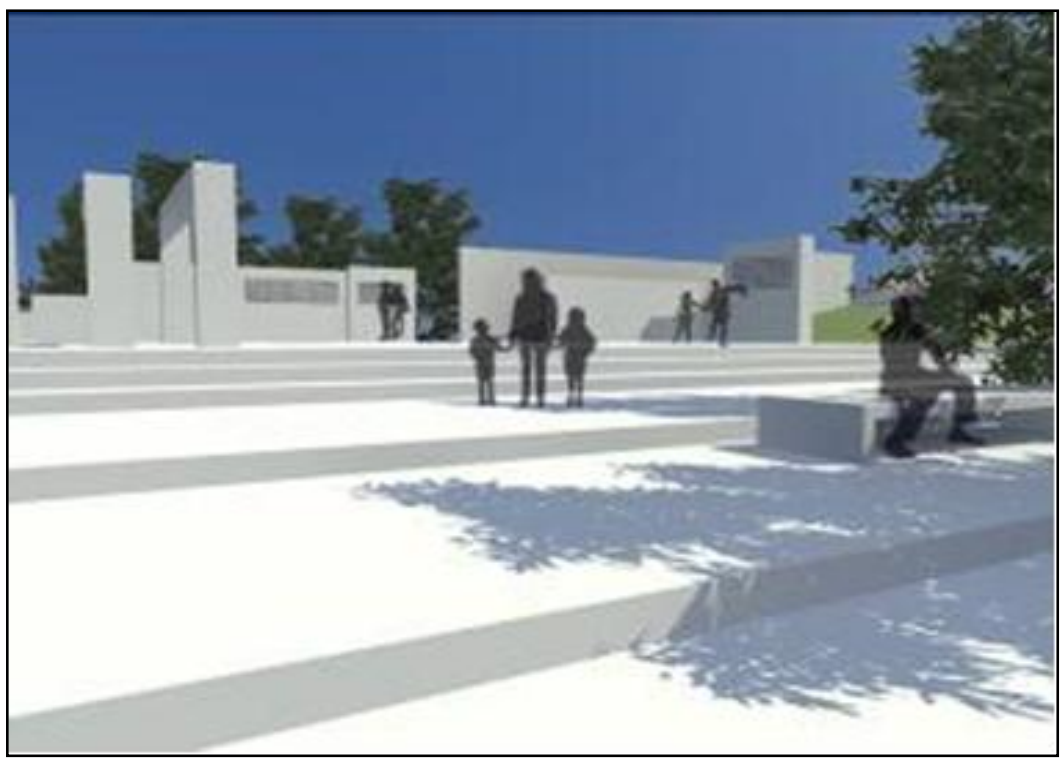

Resim 16. Nasrettin Hoca'nın Kızı Fatma Hatun'un Anıt Mezarı perspektifi [4]

(Figure 16. Perspective of the Nasreddin Hodja's daughter Fatma Hatun Mausoleum Memorial grave[4])

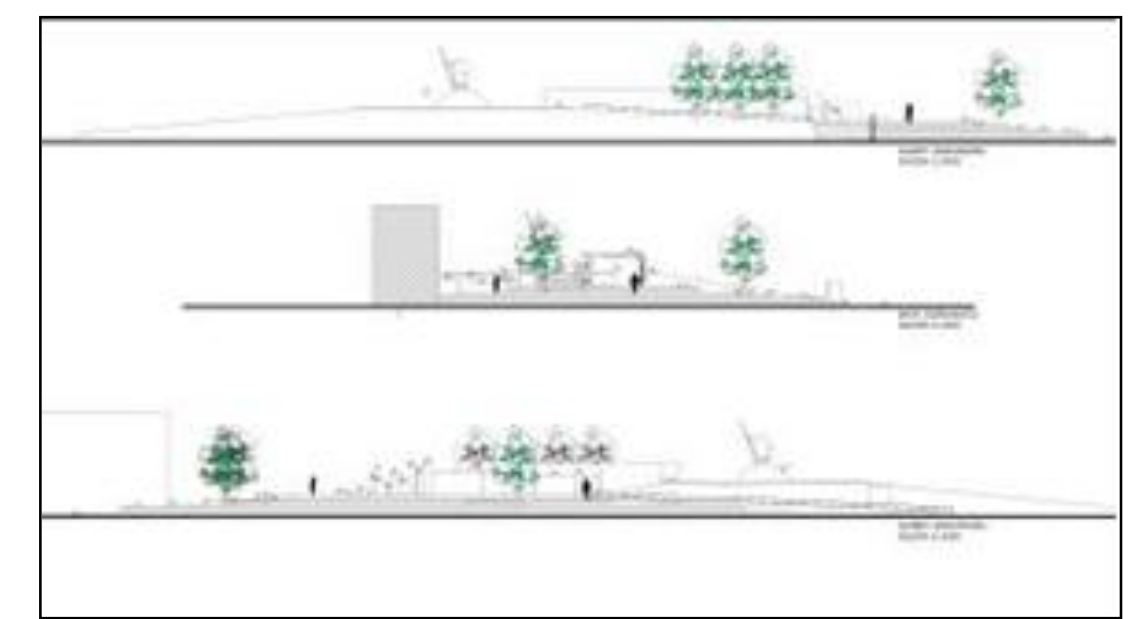

Resim 17. Anıt Mezar Kesit ve Görünüşleri ve Anıt Mezar Perspektifi[4]

(Figure 17. Sections and elevations, and perspective Mausoleum [4]) 


\subsection{Sivrihisar Belediyesi İtfaiye Bölgesi İş Merkezi Mimari Projesi(Sivrihisar Municipality Fire Zone Business Center Architectural Design)}

Sivrihisar Belediyesine ait iş merkezi mimari tasarımı Sanayi Caddesi ve Tabakhane Caddesinde bulunan eski itfaiye alanına önerilmiştir. Arazide yapı yapma alanı $2340 \mathrm{~m}^{2}$ dir. Çevresinde konut alanları, park ve çay bahçesi bulunmaktadır. Arazinin kuzey tarafında bir meydan bulunmakta ve ulaşım araçlarının park ve bekleme yeri olarak kullanılmaktadır. Bina tasarımında özellikle eğimin kullanımı ve erişilebilirlik kriterleri ön planda tutulmuştur. Yapı otopark, dükkânların bulunduğu kısım ve belediyeye ait olan kısım olarak üç bölümden oluşmaktadır ve $8797 \mathrm{~m}^{2}$ kullanım alanına sahiptir.

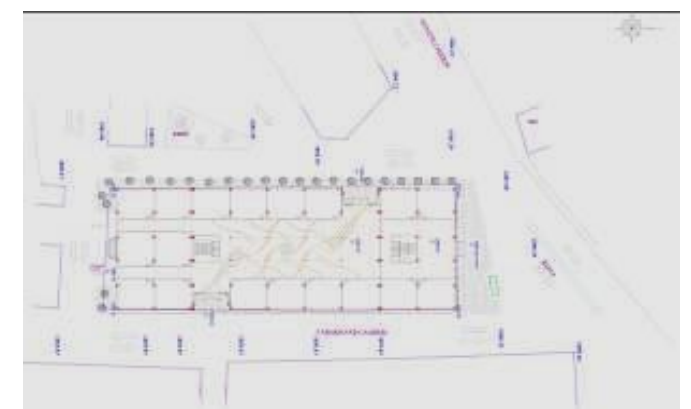

Resim 18. İtfaiye Bölgesi İş Merkezi Zemin kat planı [4]

(Figure 18. Fire Station zone, Business Centre Ground floor plan [4])

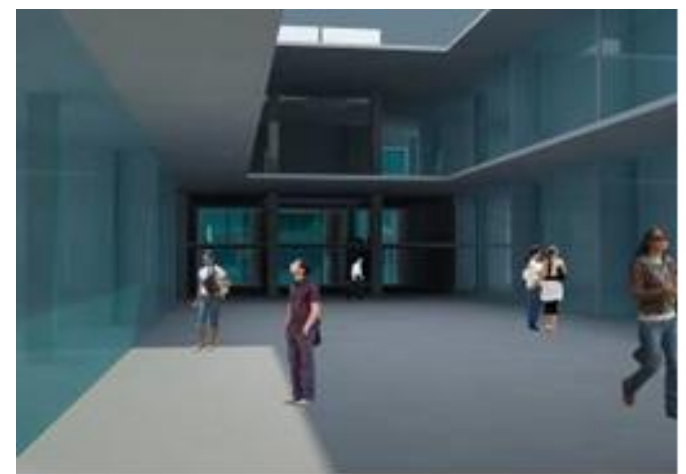

Resim 19. İtfaiye Bölgesi İş Merkezi iç mekândan perspektif [4]

(Figure 19. Interior perspective of Fire station zone and Business Centre [4])

ÜÇ kattan oluşan yapıda belediye bölümü ara kat eklenerek oluşturulmuştur. Bu yapının eğime oturmasını sağlamak ve ulaşımı daha rahat kılmak amacı ile yapılmıştır. Bu şekilde oluşturulan katlar ile yapı otopark girişleri hariç üç girişe sahiptir. Erişim kolaylığı bakımından tüm giriş katları zeminle aynı kota oturmaktadır. Bina içindeki ulaşım merdiven ve asansörler ile sağlanmaktadır. Tasarlanan yapıda belediye bölümüne ve iş merkezi bölümüne ait dükkânlar bulunmaktadır. Bu dükkânlar farklı büyüklüklere sahip iki farklı tiptedir.

Zemin kata +1085.50 kotundan doğu ve batı cephesinde iki giriş verilmiştir. Zemin katta girişler içeri çekilerek bekleme mekânı oluşturulmuştur. Kat yüksekliği 6 metre olduğu için girişi insan ölçeğine uygun hale getiren 3 metre yüksekte saçaklar yer almaktadır. Zemin katta dükkânlar, orta bölümde ise yeşil ve su öğeleri kullanılarak oturma dinlenme alanları vardır. Alanda şekil zemin ilişkisi kurularak kapılardan içeri yönlenmeyi ve oturma birimlerinin oluşumu birbiri ile ilintili olarak oluşturulmuştur. Farklı malzeme ve 
renk kullanımı ile zeminde farklılaşma yapılmıştır. Yapıda iki adet merdiven ve asansör çekirdeği vardır. 60 araçlık otoparktan teras çatıya kadar devam eden kuzey taraftaki merdiven belediye katına da hizmet etmektedir. Ara kat olan belediye katına +1088.50 kotundan giriş verilmiştir. Belediyeye ait dükkânlar bu kattadır. Girişin ön kısmı meydanlaşarak toplanma ve bekleme mekânı oluşturulmuştur. Birinci katın tamamında iş merkezi bölümüne ait dükkânlar vardır. Orta kısımda ise galeri boşluğu oluşturulmuştur ve oturma birimleri yer almaktadır. Zeminde farklı malzeme kullanımı devam etmektedir. Teras çatı kullanımı sağlanmıştır. Birinci katta yer alan galeri boşluğunun üzeri cam ve çelik örtü ile kapatılarak yapının doğal ışıktan yararlanılması sağlanmıştır. Teras katıda kullanıma açılarak oturma ve seyir alanı olarak kullanılabilmektedir.

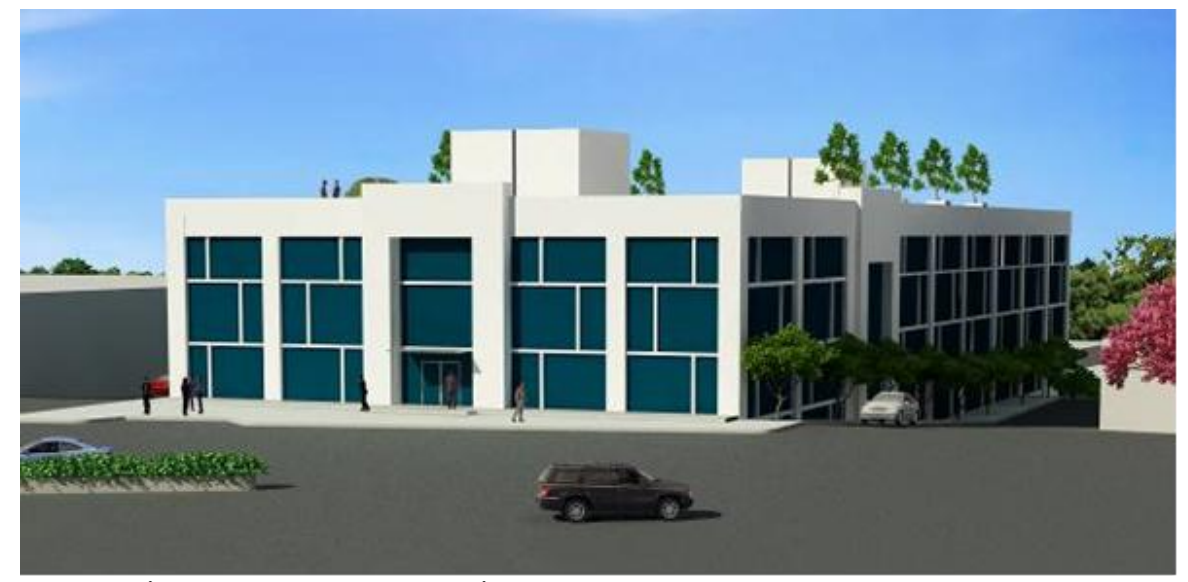

Resim 20. İtfaiye Bölgesi İş Merkezi dış mekândan perspektif [4]

(Figure 20. Exterior perspective of Fire Station Zone and Business Centre [4])

\subsection{Sivrihisar Belediyesi Sergi Parkı ve Dinlenme Tesisi Mimari Projesi (Sivrihisar Municipality Exhibition Park and Recreation Facility Architectural Project)}

Sergi parkı ve dinlenme tesisi projesi tasarımı, Sivrihisar'ın güneydoğusunda Eskişehir-Ankara yolu bitişiğinde, Uçak Müzesi batısında bulunan, belirlenmiş alana yapılacaktır. $6146 \mathrm{~m}^{2}$ alana sahip olan arsada yapı yapma alanı $4735 \mathrm{~m}^{2}$ ve arazide 3 metrelik bir eğim farkı bulunmaktadır.

Projenin tasarımında; erişebilirlik, kot farkından yararlanma, tesisin genel itibariyle çevreden algılanabilirliğinin sağlanması, kendi içinde dolaşım alanları, tesis içerisinde satış ve pazarlamaya yönelik dükkânların var oluşu ve sosyal bir doku oluşturarak insanların sosyalleşmesini ve huzurunun ön planda tutulmasını amaçlaması öncelikli kriterleri oluşturmuştur. Sosyal tesis, genel yeme içme ve kafeterya birimi, dükkânlar, havuzlar, yürüme yolları ve çocuk parkı gibi yapı birimlerinden oluşmaktadır. Yürüme alanlarının arazinin batısında yapılacak olan parkla bağlanması düşünülmüş ve iki mekânın bütünlüğünü sağlamak amaç edinilmiştir.

Yeme içme birimleri tesisin doğusunda yer almaktadır. Yapı, idari ve servis personele hizmet edecek şekilde planlanmış ve gerekli servis ekipmanının yapıya girişinin kolay sağlanması için yapı arkasından mutfak ve diğer birimlerle bağlantılı olan bir servis girişi düşünülmüştür. Yapının dış cephesinin geçirgen bir yapıya sahip olması düşünülmüş, gün ışığından en üst düzeyde yararlanılması sağlanmıştır. Yapının ön cephesinde, açık yeme içme birimleriyle ve 
genel tesisle ilişkili bir havuz konulmuş, bu alanda su öğesiyle bireylerin doğrudan ilişki kurması amaçlanmıştır.

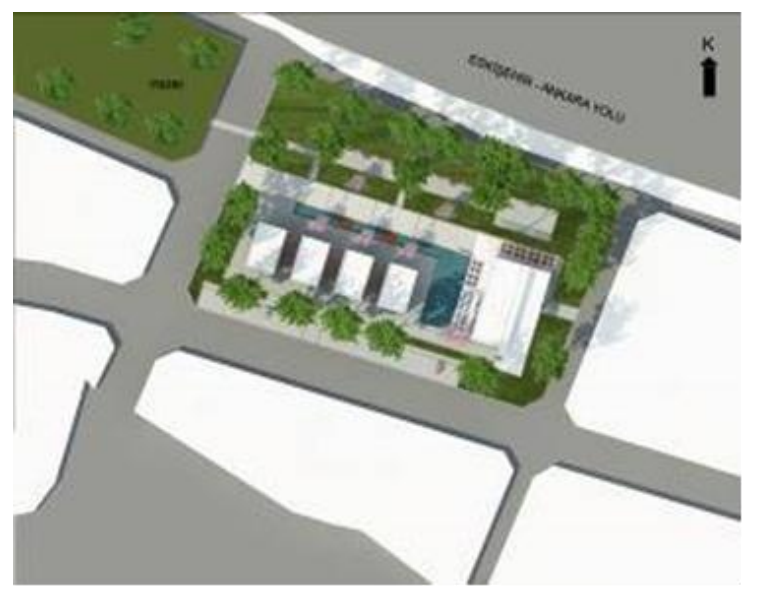

Resim 21. Sergi Parkı ve Dinlenme Tesisi Vaziyet planı [4] (Figure 21. Site plan of the Exhibition Park and Recreational Facility [4])

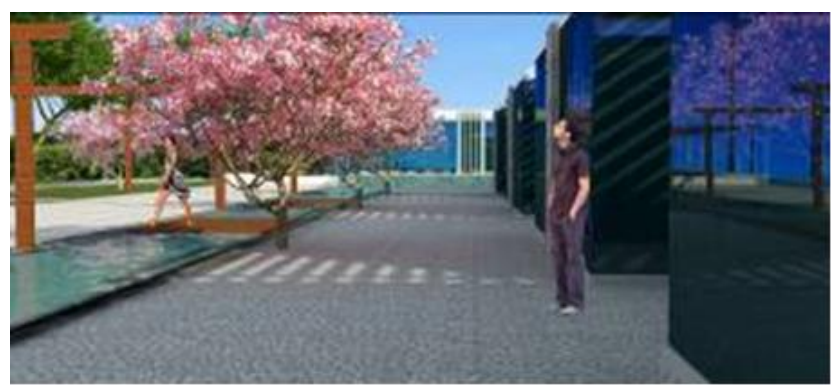

Resim 22. Sergi Parkı ve Dinlenme Tesisi Satış birimleri önünden perspektif [4]

(Figure 22. Perspective Front of the Exhibition Park and Recreational Facility [4])

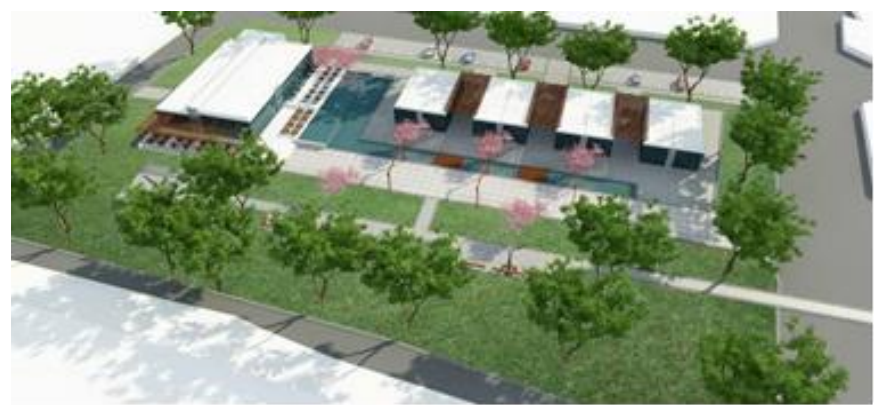

Resim 23. Sergi Parkı ve Dinlenme Tesisi Genel perspektif[4]

(Figure 23. Top view of the Exhibition Park and Recreation Facilities [4])

Dükkân birimleri tesisin batısında yer alıp her biri beş dükkândan oluşan yapı birimleri olarak düşünülmüştür. Dükkânlar arasında dolaşım aksları lineer şekilde kurgulanarak dükkânların her yönden algılanması sağlanmıştır. Dükkânlar arasında sokak dokusu oluşturulmuş, düzenli ve keyifli bir dolaşım için ortam sağlanmıştır.

Yürüme alanları arsanın kuzeyinde yer almakta olup, doğal çevreyle bütünleşen, oturma birimleriyle dinlenme olanağı sağlayan ve doğusunda çocuk parkı, batısında yapılacak olan park alanıyla bağlantılı olarak planlanmış bir yapı birimidir. 


\section{SONUÇ ( CONCLUSION)}

Toplumların geçmişe ait değerlerinin korunmasında tarihi kentlerin kültürel ve sosyal kimliklerinin sürdürülebilir olmasl gerekmektedir. Sivrihisar da kendine has gelenekleri, görenekleri, kentsel dokusu, yüzlerce yıl uygarlıkların bıraktığı tarihi mirası ve daha sayamayacağımız kadar çok verisi ile değerlerinin yaşatılması gereken kentlerden biridir. Sivrihisar'ın dar ve kıvrımlı sokakları, meydan çeşmeleri ve birbirinin görünümünü engellemeyecek şekilde konumlandırılan konutlarının oluşturduğu özgün mahalle dokusu bugüne kadar orijinalliğini koruyabilmiştir. Birçok uygarlığa stratejik konumunun sağladığı avantajlarla yerleşim yeri olmuştur ve bu sayede o uygarlıkların kültürel birikimlerini de barındırmaktadır. Kentin farklı dönemlerde inşa edilen tarihi ve kültürel yapıları bugün Sivrihisar'a ait özgün dokuyu ören yapılardır. Bu bağlamda kent genelinde sosyal, kültürel ve tarihsel bir süreklilik vardır. Ancak aynı zamanda değişen çă̆ın getirdiği ihtiyaçların da karşılanabilmesi için yeni düzenlemelerin yapılması gerekmektedir.

Sivrihisar'a yapılan kentsel tesisler doğal mekânlarla bütünleşen ve kentte süreklilik sağlayan, böylelikle kentlinin benimseyip kendine ait olduğunu hissedebileceği ve sorumluluk duyacağı mekânlar olarak kurgulanmıştır. Bu bağlamda tasarımlarda bu kriterler göz önünde bulundurulmuştur.

Anıt mezar tasarımında, anıtın sadece mezar kısmına odaklanmadan çevresi ile birlikte düşünülerek her parçanın farklı bir görev üstlendiği çeşitli yapılardan oluşan, rahat bir ulaşım ile her türlü insanın erişebileceği ve yeşil dokunun korunarak tasarıma dâhil olduğu modern bir anıt mezar tasarlanmıştır.

Sosyal tesis projesi genel olarak doğal mekânla bütünleşen, yapı ve su öğeleriyle huzurlu ve mutlu bir mekân kurgusuna sahip, aynı zamanda dükkân, yeme içme ve kafeterya birimleriyle ticari öğelere de olanak sağlayan, çok işlevli, ulaşllabilirliği kolay bir mekân olarak düşünülmüş ve bu doğrultuda bir tasarım yapılmıştır.

Sergi parkı ve dinlenme tesisi tasarımında göz önüne alınan kriterlerle farklı kotlarda yer alan girişler yapılarak rahat bir ulaşımın sağlandığı bir mekânlar sunulmuştur. İç mekânda galeri boşluğu ve doğal ışıklandırma kullanımı ile ferah bir kullanım oluşturan, yeşil, su öğeleri ve farklı zemin döşemeleri ile eğlenceli oturma mekânları bulunan bir iş merkezi tasarımı gerçekleştirilmiştir.

Sürdürülebilirliğin ön plana çıkmasıyla, bilinçli toplumlar doğaya minimum zararı verecek bir hayat tarzı oluşturma çabasına girmişlerdir. Bu çabanın yansıması, mimaride sürdürülebilir tasarımlar olarak kendini göstermektedir. Günümüzde teknolojiyle ve modern anlayışla tasarlanan sürdürülebilir yapılar gibi, geleneksel yapıların birçoğunda bu tarzın benimsendiği ve çevreyle barışık olma çabasının ürünü oldukları görülmektedir. Anadolu geleneksel mimarisinde sürdürülebilirliğin yansımaları özellikle konutlarda ve mahallelerde görülmektedir. Anadolu yerleşmelerinde birçok örnekte olduğu gibi Sivrihisar geleneksel mimarisi ekolojik ve sürdürülebilir nitelikler taşımaktadır. Kentin ihtiyaçları doğrultusunda yapılacak olan her tesisin bu sürekliliği sağlaması gerekmektedir. Özellikle topluma hizmet kapsamında yürütülen kentsel iyileştirme projelerinin bu sürekliliği sağlamaları beklenmektedir.

\section{TEŞEKKÜR (THANKS TO)}

Bu çalışmada emeği geçen ve katkıda bulunan başta; Anadolu Üniversitesi Rektörlüğü'ne, Sivrihisar Belediye Başkanlığına ve tasarımda emeği geçen Mimarlık Bölümü Öğrencilerime, ayrıca çalışmanın yayın haline gelmesinde emeği geçen Prof.Dr. Ruşen Yamaçlı ve Yük. Mimar Pınar Demirel Etli'ye teşekkür ederim. 


\section{KAYNAKLAR (REFERENCES)}

1. Acun, H., (1994). Anadolu Saat Kuleleri, Atatürk Kültür, Ankara: Dil ve Tarih Yüksek Kurumu Atatürk Kültür Merkezi Yayını.

2. Akan, E.A., (2010). "Tarihi Ahşap Sütunlu Camilerin Sonlu Elemanlar Analizi İle Taşıyıc Sistem Performansının Belirlenmesi", SDÜ Uluslararası Teknolojik Bilimler Dergisi, Cilt: 2, Sayı: 1, ss:41-54.

3. Altınsapan, E., (1988). "Sivrihisar'da Türk Mimarisi". Yüksek Lisans Tezi. Konya: Selçuk Üniversitesi Sosyal Bilimler Enstitüsü.

4. Altınsapan, E., (2004). Eskişehir Osmanlı ve Selçuklu Yapıları, Eskişehir: Anadolu Üniversitesi Edebiyat Fakültesi Yayınları.

5. Bourdeau, L., (1999). France: National Report: Sustainable Development and Future of Construction in France. France: Centre Sclentıfıque Et Tecnıque Du Batıment.

6. Dedebağı, C., (2010). "Nasreddin Hoca Kimdir?" Eski Yeni Eskişehir Valiliği Kültür Dergisi, Cilt: 2, sayı: 16, ss:19-21.

7. Doğru, H., (1992). XV.- XVI. Yüzyıllarda Sivrihisar Nâhiyesi, Ankara: Türk Tarih Kurumu Basımevi.

8. Gündoğdu, H., (1982). "Sivrihisar Alemşah Kümbetinin Mimarisi, Geometrik ve Figürlü Plastik Süslemeleri Üzerine", Ankara: Önder Matbaası: Vakıflar dergisi, Sayı: 16, , s.135-142.

9. İnceoğlu, M. ve Aytuğ, A., (2009). Uluslararası Ekolojik Mimarlık ve Planlama Sempozyumu Kitabı, Antalya: Mimarlar Odası Antalya Şubesi Yayınları, s.187-191.

10. Karakurt, I., (2010). "Bozkirın Ulu Bilgesi", Eski Yeni Eskişehir Valiliği Kültür Dergisi, Cilt:2, Sayı: 16, ss:37.

11. Kulaksız, S., (1977). "Sivrihisar kuzeybatı yöresinin jeolojisi" - Doktora tezi, Ankara: Hacettepe Üniversitesi Fen Bilimleri Enstitüsü,

12. Özalp, T., (1960). Sivrihisar Tarihi. Eskişehir: Tam-iş Matbaası.

13. Özcan, K,. (2008). "Anadolu'da Selçuklu Dönemi Yerleşme Tipolojileri II. Karahisarlar" , Milli Folklor Dergisi Cilt: 20, Sayı: 77, ss: 94 .

14. Özmehmet, E., (2007). "Avrupa ve Türkiye'deki Sürdürülebilir Mimarlık Anlayışına Eleştirel Bir Bakıs". Journal of Yaşar University, cilt:2, sayı:7, ss:809-826.

15. Ramsay, W.M., (1960). Anadolu'nun Tarihi Coğrafyası, Mihri Pektaş (çev.), İstanbul: Milli Eğitim Bakanlığı Yayınları.

16. Sayan,Y., (2003). "Sivrihisar Evlerinden İki Örnek", Ataturk University Journal of Institute of Fine Arts, sayl:11, ss.96112 .

17. Sivrihisar Kaymakamlığı Arşivi (2011). http://www.sivrihisar.gov.tr/default_B1.aspx?content=1009, Erişim tarihi: 08.11 .2011

\section{GÖRSEL KAYNAKLAR (IMAGE REFERENCES)}

[1]ANAÜ Müh. Mim. Fak. Mimarlık Bölümü Tasarım Ofisi Arşivi, Temmuz 2011

[2]Pınar Demirel Etli Arşivi, Kasım 2011

[3] EFSAD Fotoğrafçısı Can Tezol Arşivi, Mayıs 2010

[4] ANAÜ Müh. Mim. Fak. Mimarlık Bölümü Tasarım Ofisi Arşivi 2010 